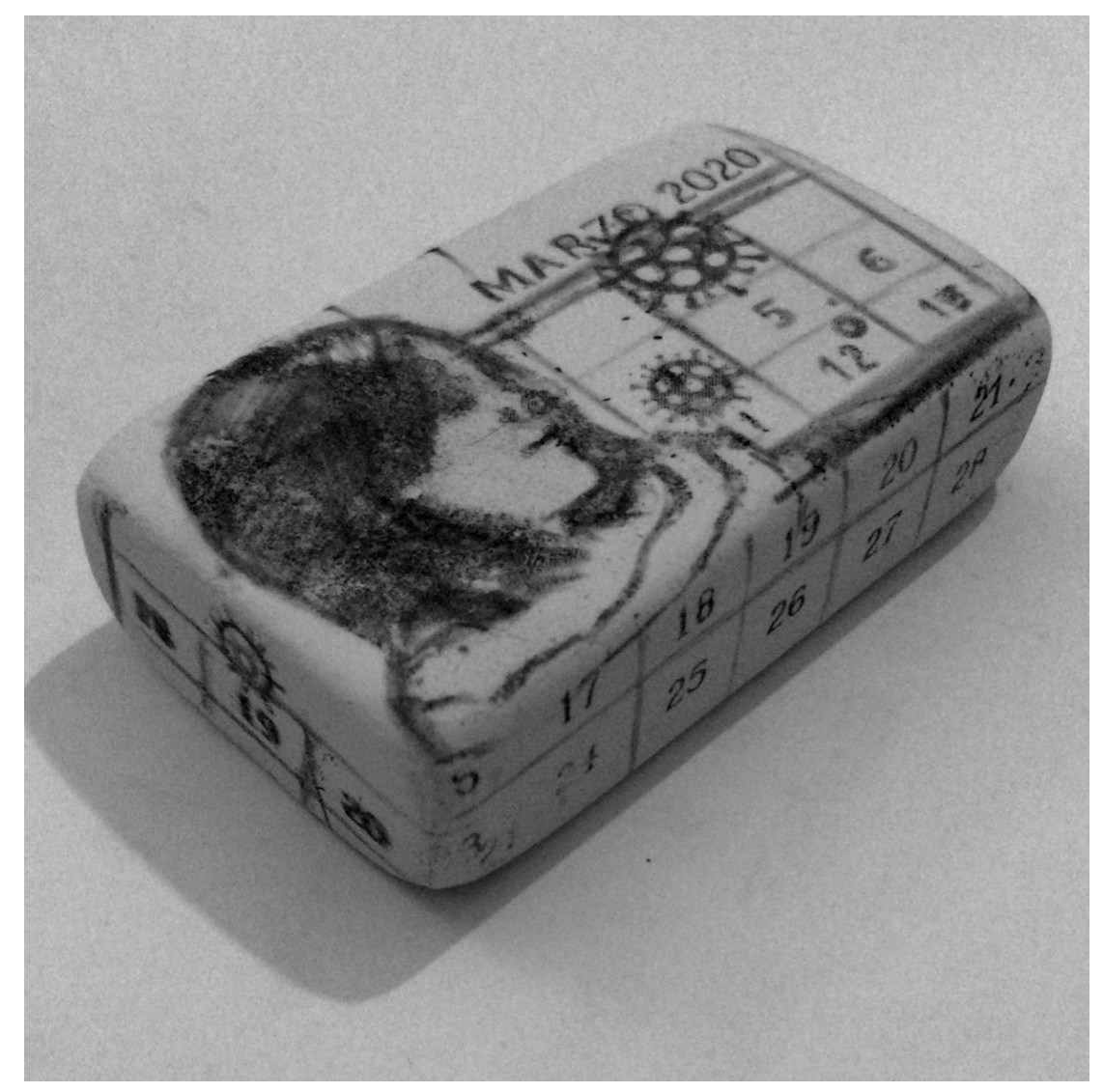

\title{
Ready made: desdibujando el pensamiento
}

\section{Técnica}

2020 [dibujo en lápiz sobre goma de borrar].

\section{Reflexión}

Objeto de borrar anulado por un dibujo. Dibujo automático, dibujo imborrable, objeto dibujo: poema objeto.

\section{Autora}

Eva C. Mesas Escobar. Bellas Artes y Arteterapeuta por la Universidad de Murcia. Miembro de MURARTT (Asociación profesional de arteterapeutas de la Región de Murcia).

Arteterapia: papeles de arteterapia y educación artística para la integración social. Monográfico: Las miradas del arte y el arteterapia en tiempos de la Covid19. ISSN-e: 1988-8309 https://dx.doi.org/10.5209/arte.75914 